\title{
Recalling Incident of Own Accident for Suggesting Better Insights
}

\author{
Salman Muhammad Soomar ${ }^{1}$ and Sarmad Muhammad Soomar ${ }^{2 *}$ \\ Aga Khan University Hospital, Pakistan
}

Submission: July 20, 2018; Published: July 31, 2018

*Corresponding author: Sarmad Muhammad Soomar, Aga Khan University Hospital, Pakistan, Tel: +92 33223835 09;

Email: soomarsarmad@gmail.com

\section{Opinion}

Quick access to emergency services for any reason is necessary that might be fatal for patients. Clients especially with fractures are quickly guided to services so that they can have an emergency treatment and other diagnostics for a better safety from that injury and secures infectious organisms to attack or enter the site. In many areas of Pakistan there are lack of facilities that can immediately tackle an accident or a fracture. In big and busy cities of Pakistan the increase in road traffic accidents (RTAs) has been so common and it's estimated that many of the deaths and disabilities occur just because of accidents around the globe and Pakistan specifically.

I recall a serious RTA that affected me during the beginning of year 2017. As a usual practice of more than fifteen days I was crossing the road similarly and was hit by a motor bike where two of the young people were recklessly riding. The hit broke my left lower leg seriously and, in few seconds, I was on ground. I checked my senses and felt like nothing else has happened and I am conscious too, but my leg is now only supported by the nerve supply and the blood supply has somewhat leaked and dropping on the ground and the remaining some blood has become a huge blood clot like a size of tennis ball.

My younger brother who was studying to be a nurse (had witnessed such a serious thing with his eyes for the first time) was in panic and started to shout and cry. We both can't recall how we moved, what else happened, who was around and what we were thinking to do. Just we can recall a huge feeling of adrenaline rush in our body and palpitations. Fortunately, the incident happened in front of a tertiary hospital in Karachi (which had good protocols and high-quality health services/standards). Somehow with a help I was managed to get to their emergency services.
As a young male, who was working to earn for a family I really felt sad that how miserable incident happened with us and recalling the event itself creates a storm in our daily life. But what we realized is I was fortunate to be so near to the hospital and because of that I was saved from complications. No doubt I was transferred in an improper way, but I was timely reached and my brother who was studying to be a nurse though panicked and got disturbed with this event was there all the time to make my transport and stay so easy and satisfying.

Unfortunately, not every case has that similar kind of situations. Other patients had very bad experiences of accidents and orthopaedic hits or fractures. They had complications and other issues due to improper emergency care and exposure to infectious agents. This is what we have heard from the victims and the clients along with us in the orthopaedic care. In my opinion, it is really necessary to have quick ambulances to pick accident or fracture victims and take them to the emergency care. Secondly, public should be trained so they must know basic things like how to immobile victim of fracture in beginning, how to transfer and where to seek help in emergency. Continuing with this, small emergency points for specific dealings regarding orthopaedic fractures must be developed and maintained in order to achieve a better care.

In addition, hospitals or emergency settings should have well versed resuscitation and trauma staff to handle the case and have an aseptic environment to secure client from microorganisms. The more we work on quick service, safe service, awareness of public and quality standards of trauma emergency care for fractures we can ensure a better outcome in victim's health. 
(C) This work is licensed under Creative (c) DYI: 10.19080/OROAJ.2018.12.555841

\section{Your next submission with Juniper Publishers} will reach you the below assets

- Quality Editorial service

- Swift Peer Review

- Reprints availability

- E-prints Service

- Manuscript Podcast for convenient understanding

- Global attainment for your research

- Manuscript accessibility in different formats ( Pdf, E-pub, Full Text, Audio)

- Unceasing customer service

Track the below URL for one-step submission https://juniperpublishers.com/online-submission.php 